\title{
An Analysis of the Role of Human Dignity in the Iranian Citizens Rights Charter
}

\author{
Fatemeh Piraman ${ }^{1}$, Seyed Mohammad Sadegh Ahmadi ${ }^{1} \&$ Masoud Raei $^{1}$ \\ ${ }^{1}$ Department of Law, Najafabad Branch, Islamic Azad University, Najafabad, Iran \\ Correspondence: Seyed Mohammad Sadegh Ahmadi, Department of Law, Najafabad Branch, Islamic Azad \\ University, Najafabad, Iran.
}

Received: June 16, 2016 Accepted: July 18, 2016 Online Published: July 31, 2016

doi:10.5539/jpl.v9n6p177 URL: http://dx.doi.org/10.5539/jpl.v9n6p177

\begin{abstract}
In today's societies, in which the variety of social communications are increasingly expanded, citizenship rights in relation to all citizens equally and without discrimination depends on a comprehensive charter. This charter should specifically predict citizenship rights. The citizenship Bill of Rights will only be successful in achieving its goals in case it is principally based on the human dignity. The Iranian legal system in 1392 experienced the development of the "Citizens Rights Charter". This charter, with its fundamental drawbacks, will not have a desirable impact on the Iranian legal system.

Apparently, human dignity enjoys a proper position in the introduction and the general rules of the Iranian Citizens Rights Charter. However, the charter's understanding of the concept of citizen and government has compromised this condition. On the one hand, considering the citizen as anonymous with the national, and granting citizenship right to the state on the other hand have compromised the the position of human dignity in the charter.

With respect to the instances of civil rights, human dignity does not enjoy an appropriate position too. The lack of distinction between instances of human rights and mere citizenship rights, non-implementation of instances in a comprehensive framework and the over-emphasis on counting the instances by the law, has undermined human dignity in the citizen rights context.
\end{abstract}

Keywords: citizen, citizen rights, citizen rights charter, human dignity

\section{Introduction}

The development of civil rights is a necessary prerequisite to achieve the ideal society envisaged by the humanity. Since the invention of an ideal society are not without effect on the real world, as they seem, but these ideas can be reflected in real societies (Morgan, 2006: 136-140; Scott \& Davis, 2007: 104-105), humanity seeks to achieve this ideal society and determine its features and characteristics. Moving from ideal to reality requires efforts through relevant channels. One of the most important such channels is the efforts to determine and thus developing citizenship rights through a comprehensive charter.

In legislative history of Iran there is no provision which is fully and independently devoted to citizenship rights. However, in 1383 the Iranian judiciary passed the "Respecting Legitimate Freedoms and Protecting Citizen's Rights Act", in order to protect citizens. But this provision just provided part of citizens rights incopletely, namely the citizens judicial rights, and lacked any special sanctions until 1394. For this reason it never found the proper position in the Iranian legal system (Fathi and Mokhtarpoor, 1390, 58). This weakness was offset by the adoption of article 7 of the Code of Criminal Procedure in 1394. There is no other law related to civil rights other than this law.

Of course, it does not mean that the Iranian legal system has not confirmed the civil rights and has never warranted the instances of civil rights. Instances of civil rights are predicted in different rights and especially the Constitution of the Islamic Republic of Iran.However, such instances are not placed in a seperate category for civil rights and they lack the required coherence. Nevertheless, the Charter of Citizens Rights, developed by the Legal Vice Presidency in 1392, has been proposed as the first comprehensive document on the issue of civil rights in the Iranian legal system. This document originates not only from the neccessity and the need for such document, but also from the obligations contained in the "Fourth Development Plan" for the government. 
With regard to the critera governing the formulation of Citisens Rights Charter, what is accepted today as the most desirable standard is the "Human Dignity". Human dignity distingushes man from other creatures and is the feature all human beings enjoy and the criterion that the main goal of the charter, which is the enjyment of all strata of society from the benefits of this law regardless of their acquired features,will be achieved (Pollitt, 1994, 21). In other words, whatever the position of human dignity in the charter is higher, the charter is more complete and the grounds will be better prepared for the achievement of its goals.

\section{The Concept of Human Dignity and the Citizens Charter of Rights}

\subsection{Human Dignity}

Human dignity is one of the concepts that historically is as old as the human life; But this concept as a basis for the development of law (especially human rights), is novel. However, it does not mean that the content of the concept of human dignity is now clear and free from ambiguity. In fact, this concept is amongst the concepts which is controversial in terms of meaning. The origin of this dispute has roots in the ambiguities of the content, scope and the basis of acceptance of this concept (Jacobson, 2007, 292).

In Persian language the word "dignity" is translated as: value, reverence, prestige, magnanimity, esteem, honor, humanity, status, place, degree, rank, place, position, freedom from baseness and pollution, kindness and forgiveness, chivalry (Dehkhoda, 1373, vol 11, 1670). Elsewhere, this word means: eminence, pride, venerability, magnanimity and esteem (Moein, 1388, 854).

The word "dignity" is derived from the latin word "dignitas", which means honor, prestige, pride and to deserve respect (Oxford, 1996, 398). In Oxford short dictionary this word is translated as magnanimity, esteem, honor, real value, degree and rank (Short Oxford, 2002, 679).

As it stands, differences even spread to the literal meaning of the term dignity (Habibzadeh and Rahiminejad, 1386, 55; Alavi, 1389, 158). Literally, some meanings for the word dignity refer to the changing characteristics of human, such as social, political, religious and occupational characteristics that certainly varies from person to person. While some of the other characteristics refer to human in the capacity of human, in the sense that simply being a human, regardless of the characteristics and conditions that may exist, matters.

The same argument applies in the area of literal meaning. In terms of meaning, although there have been some debates in the sphere of human dignity, but they have not yielded in a legal definition of this concept. Although in international law human dignity has always been considered as an ideal and reliable basis, there exists no definition of this concept in this context too.Therefore, in order to achieve the meaning of the term "human dignity" one should refer to the definitions offered by the scholars in this regard.

Basically, the Islamic scholars examine the dignity in two separate fields: inherent dignity and acquired dignity. Some others, with little change in terms and attention to the effect and use of each of the meanings, have divided dignity into inherent worldly dignity and other-worldly acquired dignity (Alikhani, 1385, 100).

Inherent dignity: This is a kind of dignity that exists without the intervention of human will and is part of human nature. This type of dignity has no relationship with positive or negative features and social or individual characteristics of the person and it is an integral part of the person as long as he/she is alive. In contrast, the acquired dignity is a kind of dignity which is the area of human authority, will and activity. It is not part of human nature and is related to his/her acts. The acquired dignity provides superiority over other humans and is not detached from human at the time of death.

Although the above mentioned principles and definitions are agreed by the Islamic scholars, there are some differences of opinion on this issue. For example, some scholars have entered reservation in the definition of inherent dignity that belief in it is in conflict with the inherent nature of such dignity. The latter believe that: ...inherent dignity is an attribute that all human beings enjoy, unless they deprive themselves of it freely in order to betray themselves and commit a crime against themselves and others (Jafari Tabrizi, 1370, 279). As it was mentioned, there is no doubt that this definition has fundamental problems. The problem is that inherent matter can neither be deprived nor it can be ordained (Habibzadeh and Rahiminejad, 1386, 55). Therefore, what is called inherent dignity cannot be deprived even byway of commiting crimes, because it is part of human nature.

From a non-religious point of view, human dignity is defined as: "human dignity is the presige and value that all human beings enjoy equally because of their inherent independence and their intellectual and moral capacity" (Kant, 1993,214). This definition is based on "moral autonomy" theory. This definition is also criticized; since the establishment of interdependent relationship between inherent dignity and self-conscious rationality has undermined the comprehensiveness of the definition. As it stands, the drawback somehow affects the scope of 
the definition. As a result, the problem cannot be easily ignored.

Clearly, on the meaning of the term "human dignity", the attitude of religous scholars, specially Islamic ones, is different from other scholars. However, difference in the meaning of human dignity in those two attitudes fades out in terms of the legal viewpoint. In other words, part of the dignity that can have a non-violable basis for the development of general rules in the social sphere (more pricesly, in granting social rights), is not different from the non-religious attitude. The latter argument is in terms of the scope of dignity in both attitudes, not in terms of basis. These two attitudes are totally different in terms of the origin and basis of dignity.

\subsection{The Iranian Citizens Rights Charter (CRC)}

Generally, the purpose of developing a charter is to regulate the performance of authorities against the group that enjoy the rights. For instance, patients bill of rights is the set of rules developed to regulate the performance of health service providers for patients (Dargahi and Eshaqi, 1386, 91). So, it is focused on the rights which should be exercised for patients. Thus, CRC is acharter that should include civil rights; in the sense of the rights that emanate from the voluntary membership of human in a civilsociety and basically are protected and applied by government.

Based on the proposed definitions one may conclude that: Citizens Charter should, in principle, be a declaration that states the mutual rights of citizens, analyzes its application mechanisms and ultimately proviedes for its protection. In order to achieve this, the intended rights must be recognized unequivocally and without ambiguity, target individuals must be exactly determined and the organizations in charge must be declared.

In the present era, due to the increased level of social communications, incresed education and capabilities of people, the need to improve the quality of public services via emphasis in existing laws and increasing citizens' awareness (Department of Administrative Reforms and Public Grievances, India, 2002, 84), uniform protection of all citizens at all levels and positions (Politt, 1994, 21) and other such issues, existence of a basic document which can be considered as the basis for any debate on citizenship rights, will have a drastic impact on public capbility to accomplish one's rights in human societies.

In societies like Iran, which is a pluralist society composed of different social, cultural, religious, linguistic and ethnic groups, the need for greater uniformity of citizens in terms of their citizenship rights is more prominent. Due to this issue and the insufficiency of chapter 3 of the Constitution of Islamic Republic Iran, titled "the rights of nation", led the Islamic Consultative Assembly to require the government to develop and adopt a comprehensive citizens rights charter, in paragraph 100 of the Fourth Economic, Social, and Cultural Plan. In addition to this task, art 100 of the above law requires the judiciary to prepare and update the bill related to maintenance and improvement of citizenship rights. Regardless of the criticisms about determining a unit authority for develeopment and organizing citizenship rights and the consequent executive problems arising from this drawback (Dadandish, 1392, 122), the act itself is considered as a turining point in the promotion of Iranian citizenship rights.

Unfortunately, the next steps towards the realization of the Fouth Development Plan were taken slowly. The reason for this can be attributed to the lack of unit authority and prediction of two parallel powers (the Executive and the Judiciary) as guardians for the implementation of this part of the Plan, and also the lack of consensus as a process through which the views of members of a social unit are exchanged and put under supervision and their differences are decreased (Parsons, 1385, 329) - and agreement about the topics of program.

In any event, the CRC was prepared by the Legal Vice Presidency in December 1392. But, in fact the identity and position of this document is not determined in the Iranian legal system. Given the drafter and conditions of legislation, regulations included in this charter are not considered as law, at least in its specific meaning. Even it is disputed whether the Concil of Ministers has jurisdiction for the adoption of such provision (or it is impossible because of the wide range of the charter); and incapacity to adopt may seem more logical due to the volume and act-like content of the charter.

Even though the charter was codified with significant delay, such delay did not provide for its perfectness. CRC has has drawbacks both in general principles and in examples of citizenship rights. The major problem with the CRC is that it not clear whether it seeks to expand the examples of citizenship rights or it simply tries to restate the existing examples. The terms used in the introduction of the chater makes one think that the drafters of this document, in its introduction, are not bound to the recognition and declaration of citizenship rights which have roots in the history of Iranian laws, but the have considered all the examples, whether previously predicted in laws or not. Meanwhile, the second paragraph of art 1 has expressed the opposite. According to this paragraph, the aim of the charter is only to aggregate, identification and declaration of citizenship rights, in a way that none 
of the civil rights enumerated in other regulations are limited.

Moreover, the charter suffers from ambiguity and weakness in terms of its enforcement. As it is expressed in different parts of the charter, provisions of this document are guaranteed by the existing legislation in the relevant field. As a result, the charter cannot compensate the weaknesses of other laws in terms of enforcement. However, the charter has tried to offset this deficit through mechanisms such as the establishment of a national center for citizenship rights and requiring it to report the violations of civil rights guaranteed in the laws and regulations and in the provisions of the charter to the Presidency.

In addition, the charter faces difficulty with regard to abrogation of contrary laws. In other words, in relation to those principles of the charter which are not in conformity with the laws of the country or are in conflict with them and the results of this conflict is the development of civil rights under the charter, the charter cannot abrogate or modify them in favor of civil rights.The reason is clear: considering the status of the charter among legal regulations and lack of the "law" title, and consequently non-fulfillment of a condition for abrogation, namely the equal rank of the abrogating and the abrogated or the higher rank of the abrogating provision (Mohammadi, 1390, 358). This document lacks the authority to abrogate its predecessor rules.

Despite all these shortcomings, the citizens rights charter is the only document in Iran about civil rights. This document covers civil rights in a comprehensive and specialized manner, so it is of great importance in the Iranian legal system. This document orientation towards the concept of human dignity reflects the status and significance of this concept in the legal system of Iran.

\section{The Relationshsip between Citizenship Rights and Human Dignity}

The content of citizenship rights initially reflects that it is linked with contents other than human dignity. In other words, citizenship rights have roots in acquisitive affairs, not in human dignity as an inherent matter. This is even recognizable through attention to the literal meaning of "citizen" and "citizenship rights". In persian dictionary, citizen is defined as native, urban, townsman, citizen, urban who is free from army and police service and also a person who is from a city or country and enjoys the rights which belong to it (Amid, 1363, 457). In this definition the meaning of citizen is with the society that is tied with it. Elsewhere, the literal meaning of the word "citizen" is mentioned as "a person who, by means of birth or granting him legal citizenship, is a member of the country or political society with interest and loyalty to that society and enjoys all civil rights and legal protections" (Bainbridge, 1999, 25). As it stands, in all these definitions the concept of citizenship has a direct relation with a dependency to matters outside his essence. This matter in today's societies is basically relationship with the city or in legal terms his relationship with the state and government, which ultimately leads in the establishment of nationality for the person. It can be recognized that: citizenship rights is not based on human dignity criteria.

Scrutiny in the meaning of citizenship rights confirms the above deduction. In colloquial terms "citizenship rights are rights derived from the constitution of every country, granted to individuals due to citizenship or residence in a certain country and protected by the constitution (Afandak, 1385, 51). Some scholars believe that citizenship rights are part of constitutional law with national dependence and attachment (Shams Nateri et al, $1387,15)$. Elswhere it is mentioned that "citizenship is a group of people the members of which are connected to each other as a result of material and spiritual factors. They have a sense of belonging to the community and feel they have a common destiny with other members of the community" (Ghazi shariatpanahi, 1375, 56). In fact, citizenship concept reflects the relationship between the individual and society in terms of rights and responsibilities (Falex, 1385, 15). Almost in all idiomatic meanings for the citizenship rights, one could see the effect of nationality on gaining those rights.

It seems that, even in the Islamic approach towards the citizenship there are factors external to human dignity; though not in the meaning that is considered in today's law for nationality. In the viewpoint of Islam, the criteria for citizenship is to worship the creator and religion is central. However, in this approach ancillary nationality, as emergency and secondary, under the title "national citizenship" - that a gathering of human beings with national ties such as same language, same race and same culture which forms a nation - has been accepted; but in Islamic point of view Ummah or Islamic nationality, in a sense that the linkage based on which only muslim and faithful people gather together comprise a single nation, forms the main basis of nationality. Infact, Islam has always tried to replace the "assembly of citizens" with the "community of believers" (Khalilian, 1341, 62). Therefore, the main purpose of explaining the obligation pact ${ }^{1}$ is to provide a secure environment and agreement and peaceful coexistence between different religious sects inside the territory of the Islamic government (Amid 
Zanjani, 1376, 58).

So, national in Islam means muslim and all non-muslims are considered strangers and foreigners. However, non-muslims who enter the Islamic territory with a formal permission ${ }^{2}$, can cross through it or accommodate in it temporarily (Ziaee Bigdeli, 1368, 94). Religious minorities, exclusively comprised of Jews, Christians and Zoroastrians, also enjoy permanent accomodation and relatively full rights of citizenship by paying ransom and signing obligation pact (Amid Zanjani, 1376, 133).

In another approach, instead of dividing humans into nationals and non-nationals and saying that only nationals enjoy citizenship rights and non-nationals will enjoy some semi-citizenship rights in case of long stay, one may consider human at the center of enjoyment from rights and believe that all residents of a community enjoy citizenship rights and they are just divided into nationals and non-nationals with regard to part of political rights (Pello, 1370, 218). In fact, in this classification, non-enjoyment of political rights for non-national citizens is justified by their lack of duty to perform political tasks in that country. In the latter approach, the position of human dignity in codifying citizenship rights and benefitting individuals from them is more prominent. The concept of global citizen is precisely focused on this matter.

Given the drawbacks resulted from equating citizen and national, a new concept emerged and is developing increasingly. This concept is called "global citizen" and is created under the influence of globalization. In the process of globalization, the effect of geographical limitations on political and social discipline is decreased, and people are increasingly informed about the removal of such limitations (Falex, 1381, 173). Based on this approach to citizen and citizenship rights, crosslinking factors are eliminated and the need to an inherent and deep criteria in developing citizenship rights is proposed. This criteria is the criteria used in developing human rights.

Human rights is resulted from inherent human dignity and prestige. It is general and universal and to stabilize natural rights of human. Human rights is the body of rights which are universal, fundamental and absolute. While citizenship rights requires the relationship between individual and political society and the government. It is realized in the framework of government. The main part of the citizenship rights are the human rights with a certain executive mechanism (Amirarjmand, 1385, 10).

The relationship between citizenship rights and the human rights is interpreted in two ways in terms of logic. Some believe that this relationship is an absolute general-special relationship, i.e. all human rights are part of citizenship rights but some citizenship rights are beyond human rights. Some others believe that this relationship is an overlapping relationship, since human rights are rights that man has in the capacity of man and for the sake of his inherent dignity, but citizenship rights are rights that man has because of living in the society.However, since human rights documents are considered as a kind of fundamental citizenship rights documents, in most cases citizenship rights are product of the expansion of human rights and it seems that the relationship between human rights and citizenship rights is an overlapping one (Mehrparvar, 1377, 146).

As it is clear, either of the two approaches that we accept, human dignity wont lose its place in citizenship rights; the difference is that in one approach human dignity is proposed as the only reliable factor in the discussion about citizenship rights. It may be affected by the relationship between individuals and their respective governments in the other approach. In any event, even by adopting the latter approach, this concept in the context of citizenship rights is idealistic like fundamental human rights; in a way that recourse to it can improve citizenship rights and avoiding it can lead to the weakness and inefficiency of the collection.

\section{The Approach of Iranian CRC to Human Dignity}

\subsection{Concept of Free of Human Dignity in the Charter}

As was stated above, human dignity is not a concept which is agreed upon by scholars without difference. Moreover, religious and non-religious attitudes towards human dignity are different. There are differences of opinions between the two approaches. Since the origin of differences is mainly in the foundations of human dignity, these differences don't lead in significant differences in the scope of people covered by this concept.

In the discussion about the definition of human dignity in non religious approach, the focus of definition is something which is called inherent dignity in religious approach. With regard to this topic, human dignity in the legal context means inherent dignity of human, because inherent dignity is equal for all human beings and cannot be a source of political-social inequalities (Alikhani, 1385, 101). On the other hand, this dignity is inherent of human and cannot be denied. On this basis, provided that its examples are determined, it can be a general and

2. "Aman" or "Zemaan" 
reliable basis for enacting laws. Meanwhile, acquired dignity brings no advantage or superiority in political-social sphere for the owner, and everything is manifested in the afterlife (Mohammad alreyshahri, 1421, 107; and Ebn abi alhadid, 1387, 36). As a result it can never be the basis for enacting laws.

However, one of the most important conflicts in the charter is the determination of the criteria for free in human dignity. In the introduction of the charter with reference to the Holy Quran and sayings of Imam Ali, the subject of citizenship rights, "humankind" and all "creatures of god" are mentioned. This is also reiterated in tn paragraph 1-2. In this section it is expressly stated that "human dignity must always be protected and respected at the highest level". As it is clear, in these two sections the charter, in line with Islamic thought and international and regional instruments, has set the criteria of humanity for the enjoyment of citizenship rights.

There is no evidence that suggests the purpose of human dignity in the charter is the acquired dignity in the religious viewpoint. In fact, although in the Islamic viewpoint human can reach perfection through the use of his capacities and as such human behavior provide for different status and superiority over other people (Hashemi, $1384,101)$, what is satisfactorily and truly provided in the charter as a basis for citizenship rights are the grandeur and prestige of equality which all human beings enjoy as a result of inherent dignity.

The above conclusion is not absolute. Wherever the charter seeks to enumerate the people covered by the predicted rights, it seems that the approach is different. Paragraph 1-1, which enumerates the subjects of citizenship rights, only considers the national of Iran. In this paragraphwhich says all the nationals of Iran, regardless of gender, race, wealth, social class, ethnicity and the like are granted the decisions predicted in laws and regulations, the inclusion of non-muslim Iranians, including recognized religious minorities and others is ambigious. In other words, the doubt arises whether the charter by dignity means a dignity solely enjoyed by muslims.

However, it is true that the instances included in paragraph 1-1 serve as examples and are not limitative and for this reason it might be extended to all Iranians with a logical interpretation and in accordance to the introduction and general principles, regardless of their religion and sect, but it seems that given the status of religion and being one of the most important distinctive features that in many cases leads to non-compliance with basic rights, it was more appropriate to mention religion and sect in this paragraph in order to bloc interpretations that lead to exclusion of rights included in the charter for non-muslim Iranians and ultimately prove the compliance of the charter with the concept of human dignity in setting standards.

Unfortunately, the charter is written in a way that the conflict between the two practically is in favor of limiting the scope of regulations included in the charter. In other words, what is proposed in the introduction and the latter part of paragraph 2-1 is just a motto and the scope is determined according to paragraph 1-1. The same procedure is also obvious in the instances of citizenship rights. In fact, this is one of the most important conflicts of the charter, which in turn leads to other conflicts.

\subsection{The Status of Dignity in General Rules Governing the Charter}

In the introduction and first chapter of the charter human dignity is expressly considered. In the introduction human dignity is mentioned as the most important dynamic for deveoping the overall policy of government with respect to citizenship rights. This criteria is placed even upper than the constitution. In paragraph 2 of article 1 in the chapter concerning general rules governing the charter, human dignity is reconsidered and it is emphasized to protect and respect to it.

The above position is a high position and suitable for human dignity. However, in the discussion about codification of rules this position is destabilized. The destabilization is directly connected to the meaning that charter has granted to citizen a a benificiary. As it was previously stated, the concept of citizen is disputed (Ghazi Shariatpanahi, 1375, 56 and Miller, 1383, 130). However, some scholars believe that the subject of citizenship rights has been raised under the modern nation-state paradigm and it should be defined in this context (Madanian, 1390, 32); viewpoint which does not incorporate the nationality criteria into the concept of citizen is a view in line with human dignity. Since human is in the center (Madanian, 1390, 34). In the latter view, citizen is a person who lives in the territory of a country, regardless of his nationality.

CRC is not clear about the meaning of citizen, which in turn has led to the status of human dignity. In this stuation, a group of people who live in Iran and regardless of the basic argument about human dignity, Iran has approved their rights in accordance with international rules (such as refugees) are practically ignored. Indeed, the Iranian government is required to respect their rights according to international obligations. On the other hand, they are not considered eligible for receiving citizenship rights.

Another factor which destabilizes the positio of human dignity in the introduction and genral rules of the charter 
and consequently has extended to the instances of citizenship rights is the failure to determine the correct position of the government in CRC. It should be noted that the position of government in the context of citizenship rights is one of protector not establishment authority. In other words, government is by no means the drafter of citizenship rights. One of the features of citizenship rights is that this category of rights are not granted by governments, but they are enforced, protected and, in case of deficiency, amended by government. Actually, government itself is a manifestation of citizenship rights (Dadandish, 1392, 120). The basis and foundation for granting citizenship rights is human dignity. This principle is specifically undeniable with respect to instances of citizenship rights closer to human rights (Amirarjmand, 1385, 11).

Nevertheless, to maintain the position of government in the charter not only provides the grounds for a better performance of government in codification and implementation of charter provisions, but also keeps the grandeur and position of human dignity. In contrast, lack of determining the right place of government in charter not only takes the charter away from realistic and executed criteria and puts it in an ideal format, but marginalizes human dignity and weakens the effective role it could play determining citizenship rights.

It seems that in CRC government has no appropriate position. This has made the charter face a serious drawback. The view of drafters of the charter is a top down view. The charter is developed in such a way as though the government is in a position to grant citizenship rights to people. This view has provided for the centrality of government in the development of citizenship rights. Meanwhile, principles realting to development of citizenship rights and precision of charter implies that human dignity should be a priority in developing citizenship rights.

\subsection{The Status of Human Dignity in the Instances of Citizenship Rights Included in CRC}

Drawbacks in the generalities of the charter, which affects the position of human dignity and extends to instances of citizenship rights. On the other hand, the nature of instances enumerated by the charter has brought about a dual approach towards human dignity. CRC contains different and common examples of human rights and citizenship rights. On the one hand, rights such as right to life (paragraph 1-3), prohibition of torture (paragraph 92-3), right to property (paragraph 54-3), freedom of expression and belief (paragraph 11-3) which derive from inherent human dignity and prestige and are considered as human rights are seen in it, and on the other hand rights such as access to competent courts (paragraph 86-3), freedom of membership and activity in political parties (paragraph 52-3), right to establish associations and trade and professional unions (paragraph 64-3), etcare predicted which seem to be mere citizenship rights.Moreover, charter has predicted instances which are in an intermediate state, common between citizenship rights and human rights; that is to say they are both derived from inherent human dignity and prestige, and are created as a result of living in a certain society and under the influence of the facilities that exist in the society, they can differ from another society; such as the prohibition of arbitrary interference with privacy and private life (paragraph 31-3) and the right to a decent life (3-2). In view of the above and the fact that the terms "human rights" and "civil rights" have different meaning (Amirarjmand, 1385, 10 and Ghorbanzadeh, 1385, 29), inclusion of human rights instances in citizenship rights and then limiting the scope of such instances based on nationality is in no way justified. In fact, instead of dividing the humans into two categories of national and non-national and granting citizenship rights to nationals, it was more appropriate to grant citizenship rights based on human dignity and declare that: "All residents of Iran enjoy citizenship rights and citizens are just dividedinto nationals and non-nationals, with nationals enjoying the latter rights (Marshall, 1981, 34).

Moreover, lack of distinction between instances of rights defined under the citizenship rights and what is called human rights, made the government consider itself bound by affaris which are the most obvious tasks of not only governments but also civil unions (Alikhani, 1385, 103). This condition does not promote the status of citizenship rights, but destabilizes the position of human dignity even in the instances considered as human rights.

Another issue that has indirectly weakened the charter with regard to enumeration of citizenship rights, the maintenance of human dignity depends on which, is the lack of appropriate structure and suitable for the issue. Certainly, to design a reasonable structure requires the utilization of similar instruments in the regional and global level.

Obviously, given the differences in views on the issue of civil rights, there will be no full consensus about the main spheres of citizenship rights. However, it does not mean that there is no consensus on any sphere. In fact, themes originating directly from human dignity are less disputed. Today, themes such as right to freedom as a right rooted in human nature and its only limiting factor being damage to the rights of other people (Hospers, $1927,29)$, righ to equality as a right based on which the contribution of each person is determined based on his 
active and fruitful participation in social affairs; not necessarily based on equality (Marx and Engels, 1881: 71); right to security as a right derived from both freedom and equality, that today could be claimed independently and some people have interpreted it as the right to life (Sterba, 1994: 4-5); the right to life and other rights like benefitting from a relative comfort and well-being, today being a prerequisite of a sustainable social system and life (Sterba, 1985: 35; Sterba, 199: 4-5) are the main themes of citizenship rights.

Unfortunately, the charter has not based the development of instances of citizenship rights on the above themes. That is why some instances of citizenship rights which are components of human dignity are not predicted or be predicted incompletely. For example, in the scope of political rights instances, even though the right to participation in the development of country is a fundamental and human right derived from human dignity (Niroomand, 1390) and the history of Islam confirms the observance of this right by the holy prophet (Alamolhoda, 1382, 69-70), the existing laws still suffer deficits. The charter has not even tried to overcome ambiguities with regard to political rights in its predecessor legislations; issues such as the requirement to be "a political figure" for presidency candidates, and preconditions like belief and practical commitment to velayet-e faghih (Leadership), which in turn restricts the scope of political participation and is in conflict with human dignity (Tavassoli and Nejati hosseini, 1383).

Another example for deficiency of the charter is the issue of judicial security. In the area of judicial security, which is an integral part of honorable life and worthy of human dignity and prevents the abuses of rights and freedoms of citizens (Hashemi, 1390, 276) faces serious drawbacks. the charter's failure is also obvious in judicial rights of citizens. Another weakness of the charter in this sphere is the lack of express statements with regard to violent punishments contrary to human dignity, which are applied in accordance with laws but considering their nature they are interpreted as contrary to the sense of justice (Gasen, 1379, 80). Even though some scholars acquire this principle from the context of the Constitution (Rahiminejad and Habibzadeh, 1387), the fact is that the Iranian legal system is ambiguous in this issue. On the other hand, the issue of determining violent punishments contrary to human dignity has always faced with difficulty (Clarkson, 2011, 117). Nevertheless, the charter is also silent about it.

Another issue that has paved the way for violation of human dignity in the instances of citizenship rights included in the charter, is the restriction of the scope of rights included in the charter. All over the charter one could see that after predicting a citizenship right, that right is immediately restricted by the laws and regulations. Yo restrict the wide scope of the rights in accordance with law is common, but it seems that the charter occasionally transcends the moderation boundaries. For example, limiting the freedom in some areas such as creation of intellectual, literary or art works practically paves the way for personal attitudes towards the three mentioned areas, and ultimately leads to abuses, which in turn is against human dignity.

Extreme restrictions in the charter sometimes lead to unreasonable outcomes. For instance, paragraph 78 of article 3 is developed in order to eliminate discrimination. However, this paragraph has two serious problems. First, in this paragraph the term "unjust discrimination" is used, which in turn confirms some kinds of discriminations against citizens, namely "just discrimination". In addition, the paragraph continues to say that the government will address such unjust discriminations "in accordance with laws". Unreasonable result of the recent statement is that: There are unjust discriminations recognized by law, and as a result the law will not deal with them!

In addition to weaknesses and violation of human dignity in some cases, it should be noted that in some instances of citizenship rights the charter accepts human dignity in an appropriate manner and developed rules baed on it. Those instances are in all areas such as civil, political, social ... rights. In some cases the charter, considering human dignity in relation to its predeccessor laws, has a better performance. For example, in the social rights isuue, violation of the rule included in social security law and applying the principle of pervasiveness is one of the strenghts of the charter. Having restricted this principle, the social security law is based on supporting workers who pay premium (Naeemi, 1389, 14). Meanwhile, the charter confirms that social security is the right for every Iranian individual and it is the duty of government to cover all people by social security system.

\section{Conclusion}

The following results were obtained from the research:

- Although there is no consensus about the meaning of human dignity, but the differences are related to the origin and roots of this concept. Therefore, such disputes have little impact on the scope of the concept with regard to individuals. So, what is accepted in religious attitude as human dignity is in conflict with this very concept in non-religious attitude. 
- $\quad$ CRC in the present condition suffers from fundamental drawbacks, including the lack of appropriate status in legal system, non-utilization of appropriate sanctions, lack of power to abrogate conflicting laws and so on.under this condition, even assuming a favorable position for human dignity in the charter, this instrument is unable to play an effective role in the Iranian legal system.

- $\quad$ It would be desirable if human dignity be considered as dominant factor in developing a citizenship charter and be modified in some instances of citizenship rights, such as right to membership and activity in associations and unions, which are somehow tied with the nationality of citizens.

- In general, it seems that the meaning granted to human dignity by the charter is the general meaning inherent to all humans, and acquisitive factors, even religious beliefs, don't exist in it. However, as to the instances of citizenship rights, charter has violated this rule.

- Human dignity enjoys a high position among the general principles of the charter. But, factors like incorrect definitions of human dignity and also granting an improper position to government, in such a way that government can enact citizenship rights, destabilizes this position.

- Instances of citizenship rights are flawed by three general factors: 1- The incorporation of human rights instances, citizenship rights instances and dual rights has brought about inconsistency in adjusting those instances with human dignity and damaged the status of human dignity. 2- lack of a systematic and principled frameworkhas led to prediction of some citizenship instances that are in conflict with human dignity or be predicted incompletely. 3- Charter overemphasis on restricting citizenship rights to laws has occasionally destabilized the status of human dignity.

\section{References}

Afendak, K. (1385). Citizenship and Judicial rights, Citizenship rights articles. Maku: Azad University.

Alamolhoda, A. (1382). Religious democracy and social structure of Islamic community, Islamic university, No 20.

Alidoosti, N. (1388). Police and teaching citizenship rights, Strategic studies quarterly, Year 12, No 2.

Alikhani, A. A. (1385, Summer). Human dignity and violence in Quarn. Political sciences journal, (3).

Amid Zanjani, A. (1376). Minorities rights (4th ed.). Tehran: Islamic culture pubilcation.

Amid, H. (1369). Amid Persian dictionary. Tehran: Amirkabir publication.

Amirarjmand, A. (1385). Principles of citizenship rights and human rights, Etemad Melli, No 188.

Bainbridg, D. (1999). Intellectual Property (4th ed.). Pitman Publishing.

Clarkson, C. M. V. (1987). Understanding criminal law. London: Fontana press.

Dadandish, P., Amini Ahmadabad, A., \& Kananian, S. (1392, Fall). Challenges of developing a citizenship rights charter in Iran with an emphasis on article 100 of $4^{\text {th }}$ development plan law. Rahbord quarterly, Year 22, (68).

Dargahi, H., \& Es'haghi, S. (1389). comparative study of patient rights in selected countries with Iran. Iran Diabetes and Lipid journal, Medical ethics journal.

Dehkhoda, A. (1373). Dictionary (Vol. 11, 1st ed.). Tehran: University of Tehran publication.

Department of Administrative Reforms and Public Grievances, Government of India. (2002). Citizens' Charters: Indian xperience. $\quad$ Retrieved March 1, 2008, from http://darpg.nic.in/arpgwebsite/reforminitiatives/CitizenCentricInitiative/ Citizens-ChartersIndianExperience.asp

Ebn Abi Hadid. (1387). Explanation of Nahjolbalaghe (Vol. 7, research: Mohammad Abolfazl Ebrahim). Beirut: Dar Ehya Altarath Alarabi.

Ebn Manzoor. (1405). Jamalodin Mohammad ebn Mokarram, Lesanol Arab (Vol. 12). Ghom: Adabolhawzah publications.

Fallex, K. (1381). Citizenship, translated by Mohamadtaghi Afruz. Tehran: Kavir publication.

Farahidi, Khalil bin Ahmad. (1410). Al'ayn (Vol 5). Beirut: Darolhojrah institute.

Filizola, Z., \& Gerar, L. (1379). Victim and victimology, translated by Rohodin Kordalivand and Ahmad Mohamadi (1st ed.). Tehran: Majd publication. 
Ghazi Shariatpanahi, A. (1375). Principles of public law. Tehran: Dadgostar publication.

Ghorbanzadeh, H. (1385). Maintaing citizenship rights in the light of principles governing equitable procedure, Criminal law thesis, Emam Sadeq university.

Habibzadeh, M., \& Rahiminejad, E. (1386, Winter). Human dignity in the cnstitution of IRI. human sciences quarterly, (4).

Hashemi, M. (1384). Constitutional law of the Islamic Republic of Iran (1st ed.). Tehran: Mizan publication.

Hashemi, M. (1390). Human rights and fundamental freedoms (1st ed.). Tehran: Mizan publication.

Hospers, J. (1972). The Libertation Manifesto. In J. P. Sterba (Ed.), 1999.

Jacobson, N. (2007, January). Dignity and health: A review. Social Science \& Medicine, 64(2). http://dx.doi.org/10.1016/j.socscimed.2006.08.039

Jafari Tabrizi, M. (1370). Human rights in Islamic and Western point of view. Tehran: International legal services office of Iran.

Kant, I. (1993). The Metaphysic of morals, Trans and ed. Mary Gregor, Cambridge university press.

Khalilian, K. (1341). Islamic international law. Tehran: Keyhan publication.

Madanian, G. (1390). discussion about the meaning and concept of citizen. University of Tehran: Pardis Ghom Faculty of law.

Marshall, T, H. (1981). afterthought on value-problem of welfare-capitalism, the Hyphenated Society. In Marshal, T. H. (Hrsg.), 1981: the right to welfare and other essays, London/Edinburg/Melbourne u. a.

Marx, K., \& Engels, F. (1881). The Socialist Ideal. In J. P. Sterba (Ed.), 1999.

Mehrpour, H. (1377). Human rights law international system (1st ed.). Tehran: Ettelaat publication.

Miller, D. (1383, Spring). Human rights and citizenship bound to borders. Rahbord quarterly, (23).

Moein, M. (n.d.). Moein dictionary (12th ed.). Tehran: Amirkabir publication.

Mohammadi Alreyshahri, Mosua Emam Ali, Ghom: Darolhadis, 1421.

Mohammadi, A. (1390). principles of deducting rules (15th ed.). Tehran: University of Tehran publication.

Morgan, G. (2006). Images of Organization. Updated edition, Sage Publications.

Naeemi, O. et al. (1389). Social security law of Iran in the present legal system. Jungle publication.

Nirumand, L., \& Vahednavan, A. (1390, Spring). Media and new methods of citizenship participation, Media studies, Year 6, No 12.

Parsons, D. (1385). principles of public policy and policy analysis, translated by Hamidreza Malekmohammadi. Tehran: Institute for strategic studies.

Pello, R. (1370). Citizen and Government,Translated by Abolfazl Ghazi. Tehran, University of Tehran Publication.

Pollitt, C. (1994). The Citizen's Charter: A Preliminary Analysis. Public Money \& Management, 14(2). http://dx.doi.org/10.1080/09540969409387809

Pradel, J. (1373). History of criminal thoughts, translated by Ali Hossein najafi Abrandabadi. Tehran: Shahid Beheshti University Publication.

Rahiminejad, E., \& Alavi, M. (1389). An introduction to the concept, principles and effects of human dignity in criminal law. Allameh law, (24).

Rahiminejad, E., \& Habibzadeh, M. (1387). Inappropriate punishments: punishments contarary to human dignity. Law quarterly, Faculty of law journal, (2).

Rawls, J. (1989). The Domain of the Political and Overlapping Consensus. New York University Law Review, 64 N.Y.U.L. Rev. 233.

Shams Nateri, M., \& Atazadeh, S. (1387). Criminal protection of citizenship rights in Iran, Karagah, No 4.

Short Oxford English Dictionary. (2002). Fifth Editation, vol 1. Oxford University Press.

Tavasoli, G., \& Nejati Hosseini, M. (1383). Social reality of citizenship in Iran. Iranian Sociology magazine, (2).

Taylor, D. (2000). An Introduction to social policy: Values in social policy. The Robert Gordon University Press. 
The Oxford Encyclopedia, English Dictionary. (1996). New York, Oxford University Press.

Ziaee Bigdeli, M. (1383). Islam and international law. Tehran: Ganje Danesh publication.

\section{Copyrights}

Copyright for this article is retained by the author(s), with first publication rights granted to the journal.

This is an open-access article distributed under the terms and conditions of the Creative Commons Attribution license (http://creativecommons.org/licenses/by/4.0/). 